\title{
Brown spot disease severity, yield and yield loss relationships in pigmented upland rice cultivars from East Nusa Tenggara, Indonesia
}

\author{
YOSEP S. MAU ${ }^{1,2, \boldsymbol{v}}$, A.S.S. NDIWA ${ }^{1}$, SHIRLY S. OEMATAN ${ }^{1}$ \\ ${ }^{1}$ Department of Agrotechnology, Faculty of Agriculture, Universitas Nusa Cendana. Jl. Adisucipto, Penfui, Kupang 85001, East Nusa Tenggara, \\ Indonesia. Tel./fax.: +62-380-881085, "email: yosepmau@yahoo.com \\ ${ }^{2}$ Archipelagic Dryland Center of Excellence (Pusat Unggulan Ipteks/PUI Lahan Kering Kepulauan), Universitas Nusa Cendana. Jl. Adisucipto, Penfui, \\ Kupang 85001, East Nusa Tenggara, Indonesia
}

Manuscript received: 10 February 2020. Revision accepted: 24 March 2020.

\begin{abstract}
Mau YS, Ndiwa ASS, Oematan SS. 2020. Brown spot disease severity, yield and yield loss relationships in pigmented upland rice cultivars from East Nusa Tenggara, Indonesia. Biodiversitas 21: 1625-1634. Brown spot is one of the most devastating diseases of rice, which could lead to total yield loss. The disease has a worldwide distribution, more specifically in areas where water supply is scarce, most specifically in the dry upland areas. Almost all stages of rice are affected by the disease, where leaves and grains are mostly affected. Considerable differences exist in susceptibility to brown spot among rice varieties, which may cause a large variation in yield loss caused by the disease. Therefore, the resistance level of rice varieties and their yield reduction has to be regularly evaluated and updated. There are only a few reports on the relationship between brown spot severity with yield and yield loss of upland rice, and is even lacking in pigmented upland rice. The objectives of the present study were to assess the brown spot severity and resistance level in pigmented upland rice cultivars from East Nusa Tenggara Province, Indonesia, and to elucidate their relationships with yield and yield reduction. Twenty four pigmented upland rice genotypes were evaluated in the field during May to October 2019, and their disease responses and yields were recorded. Disease severity was observed weekly and used to calculate Area Under the Disease Progress Curve (AUDPC) for comparison among the genotypes. The relationships between disease severity and AUDPC with yield and yield loss were also examined. The results showed significant variation in brown spot severity and AUDPC, ranging from, respectively, $11.11 \%$ to $40.70 \%$ and $398.42 \%$-days to $1081.30 \%$-days. Yields and yield losses of test genotypes also varied substantially. Yields under diseasedfree and diseased plots ranged from, respectively, $2.34 \mathrm{t} \mathrm{ha}^{-1}$ to $6.13 \mathrm{t} \mathrm{ha}^{-1}$ and $1.68 \mathrm{t} \mathrm{ha}^{-1}$ to $3.74 \mathrm{t} \mathrm{ha}^{-1}$ while yield loss was between $10.46 \%$ and $56.15 \%$. Six genotypes were moderately resistant, four genotypes were moderately susceptible and 14 genotypes were susceptible to brown spot. Neither disease severity nor AUDPC had a linear relationship with yield but both exhibited positive and linear relationships with yield loss.
\end{abstract}

Keywords: Brown spot, pigmented upland rice, yield loss

\section{INTRODUCTION}

One of the major diseases of rice (Oryza sativa L.) is brown spot caused by Drechslera oryzae (Breda de Haan) Subram. \& Jain [syn. Helminsthosporium oryzae, Bipolaris oryzae; teleomorph: Cochliobolus miyabeanus (Ito \& Kurib)](Mew and Gonzales 2002). Brown spot is the most devastating disease of rice, which could cause considerable yield losses, both in terms of quantity and quality (Savary et al. 2000, 2005; Jha 2001; Goel et al. 2006; IRRI 2009; Singh et al. 2017). Losses in yield up to $90 \%$ had ever been recorded, which contributed to the Bengal Famine of 19421943 (Padmanbhan 1973).

Drechslera oryzae can infect both seedlings and mature plants. The disease symptoms mostly occur in leaf blades but can also be found on other plant parts such as the coleoptiles, leaf sheaths, panicle branches, glumes, and spikelets (Zadoks 2002). The distinctive symptoms of this disease include lesions with light reddish-brown color or lesions with a gray center surrounded by a dark to reddishbrown margin with a bright yellow halo (Ou 1985). These lesions will reduce the leaf photosynthetic area and the efficient use of nutrients, which may cause yield reduction (Lee 1992; Mew and Gonzales 2002; IRRI 2009).
Brown spot has been reported to have a widespread distribution in all rice-growing areas of the world $(\mathrm{Ou}$ 1985; Singh and Singh 2000; IRRI 2009; Reddy et al. 2011; Aryal et al. 2016). The disease is also reported to occur more frequently and severe due to climate change, especially in the condition of prolonged drought (Savary et al. 2005), which may likely due to increased variability in rainfall (Barnwal et al. 2013). Brown leaf spot of rice is also known to occur mostly in nutrient deficient and poor soils (Agarwal 1989; Zadoks 2002). Among these soils are upland agroecosystems where most upland rice cultivars are grown by poor farmers. In the recent time of global warming and climate change, where prolonged drought and erratic rainfall are frequently occurring, thus, brown spot will become more severe and devastating in upland rice, which may result in higher yield reduction. Up to date, however, reports on yield loss caused by brown spot in upland rice is lacking, and so does the relationship between brown leaf spot severity and yield loss in upland rice germplasm.

Recorded yield losses caused by brown leaf spot of rice vary greatly among upland and lowland ecosystems, as well as across countries/regions. Even, the variation occurs among rice genotypes being cultivated. The disease has 
been recorded to cause yield reduction from $6 \%$ to $90 \%$ in Asia (Padmanabhan 1973; Singh and Singh 2000; Mew and Gonzales 2002; Aryal et al. 2016). Brown leaf spot was also reported to cause yield loss of, on average, $10 \%$ in all lowland rice production in South and Southeast Asia (Savary et al. 2000, 2005), and severely infected field can suffer up to $45 \%$ yield reduction (IRRI 2012). In India, brown spot was recorded to reduce tiller number and also reduce the yield of 19.2-58.8\% (Vidhyasekaran and Ramadoss 1973; Chattopadhyay et al. 1975). In Africa, yield loss caused by brown leaf spot was reported about $12 \%$ in Nigeria (Aluko 1975), and from $8 \%$ to $23 \%$ in North Sierra Leone (Fomba and Singh 1990). Meanwhile, reports on yield loss caused by brown spot in Indonesia are unavailable at present.

Control of brown spot can be done through various methods, including the use of disease-free seeds, the use of resistant varieties, balanced nutrition, avoidance of water deficit, and fungicide spray (Ou 1985; Mew and Gonzales 2002; Zadoks 2002; Mandal and Jha 2008; Asghar et al. 2019). Among these, the use of resistant varieties is the most economical and eco-friendly way of controlling the disease (Haq et al. 2002; Mew and Gonzales 2002; Zadoks 2002; Magar 2015). However, the resistant varieties are limitedly available and the resistance is not stable due to the appearance of new virulent races of the pathogen (Goel et al. 2006; Asghar et al. 2007; Katasntones et al. 2007; Arshad et al. 2008).

Significant differences exist in resistance/susceptibility to brown spot among rice varieties (Shukla et al. 1995; Datnoff and Lentini 2003; Hossain et al. 2004; Satija et al. 2005; Goel et al. 2006; Pantha et al. 2017), which may lead to a large variation in yield loss caused by the disease. The resistance level of rice varieties and their brown spotinducing yield reduction, therefore, need to be regularly evaluated. There are only a few reports on the relationship between brown spot severity and yield of upland rice. Pantha et al. (2007) found a negative correlation between grain yield with AUDPC $(\mathrm{r}=-0.628 * *)$. This type of relationship will vary among ecosystem and rice gene pool/ germplasm examined as variation in resistance/ susceptibility levels that exist within the germplasm will give variable yield losses. Thus, it is necessary to examine this kind of relationship in different germplasm, including that in pigmented upland rice, which is not available at present. The objectives of the present study were to assess the brown spot severities and resistance level in pigmented upland rice cultivars from East Nusa Tenggara (ENT) Province, Indonesia, and to elucidate their relationships with yield and yield reduction.

\section{MATERIALS AND METHODS}

\section{Study location and period}

The present study was conducted in the farmer's field in Lasiana Village, Kupang District, East Nusa Tenggara, Indonesia, during May to October 2019. The research site was located at $\mathrm{S} 10.13219^{\circ}$, E $123.67496^{\circ}, 46 \mathrm{~m}$ above sea level (asl). The soil type of research location was Entisol.
Daily mean temperature during the study period ranged from $26{ }^{\circ} \mathrm{C}$ to $28{ }^{\circ} \mathrm{C}$, while the minimum and maximum temperatures were, respectively, 21-24 ${ }^{\circ} \mathrm{C}$ and $32-34{ }^{\circ} \mathrm{C}$. Mean relative humidity was $65-72 \%$ in range (Stasiun Klimatologi Lasiana Kupang 2019).

\section{Plant materials}

Twenty-four pigmented (red, purple and black kernel) upland rice genotypes were used in this study, consisted of 21 local cultivars, two Indonesian released red rice varieties (INPAGO 7, AEK SIBUNDONG) and one breeding line of black rice (B13784C-MR-2-2-8-4-1-1-33 ). The Indonesian released varieties were kindly provided by Indonesian Rice Research Institute, Sukamandi. The breeding line of black rice was provided by Dr. Buang Abdulah (personal communication) from Indonesian Rice Research Institute, Muara, Bogor.

\section{Experimental design and procedures \\ Experimental design}

The experiment in the field was laid out in a Randomized Block Design. The experimental field was divided into two experimental sets, one for disease-free (un-inoculated) plot as control and one for diseased/ inoculated plot. Each experimental set consisted of 24 upland rice genotypes as treatments; each treatment had three replicates.

\section{Plant cultivation and maintenance}

After the planting field was cleared from weeds and plant debris, it was divided into two sets, one for uninoculated and another for inoculated plots. Each set comprised of three planting blocks facing east-west direction. Twenty four plots measuring $1.5 \mathrm{~m} \mathrm{x} 1.5 \mathrm{~m}$ were prepared within each block, with a total of 72 plots in each experimental set. Between-block spacing was $100 \mathrm{~cm}$ while the spacing between plots was $50 \mathrm{~cm}$.

The plots were irrigated until field capacity level before sowing the rice seeds. The planting holes of $25 \mathrm{~cm} \times 20 \mathrm{~cm}$ spacing were seeded with three seeds each, and after two weeks, only one plant per hole was retained until harvest.

A compound NPK fertilizer (16: 16: 16) was applied twice; as a basal fertilizer at the time of planting and at 45 days after planting. The dosage of each fertilizer application was $20 \mathrm{~g} \mathrm{plot}^{-1}$ or equivalent to $200 \mathrm{~kg} \mathrm{ha}^{-1}$. An additional urea fertilizer $(\mathrm{N}=45 \%)$ was applied at 30 days after planting at a rate of $10 \mathrm{~g} \mathrm{plot}^{-1}\left(100 \mathrm{~kg} \mathrm{ha}^{-1}\right)$. Weeds were removed manually and irrigation was provided daily to maintain field capacity level. A net/screen house was built surrounding the planting field at the panicle formation stage to prevent the rice grain from birds and rice bug (Leptocorisa acuta Thunberg). The latter was also controlled by using insecticide spray (Decis $25 \mathrm{EC}$ ).

\section{Preparation of conidial suspension and plant inoculation}

Drechslera oryzae isolate was propagated on the potato dextrose agar medium in a petri dish for 14 days. The pure culture of each fungus isolate was then rubbed using an image brush No.10 and $10 \mathrm{~mL}$ sterile water containing $0.02 \%$ Tween 20 to get a conidial solution. The number of 
D. oryzae conidia in the stock solution was counted using a hemocytometer, and an inoculum solution with a conidial concentration of $2 \times 10^{5} \mathrm{~mL}^{-1}$ was prepared for inoculation of the rice plants in the inoculated plots. Inoculation was done on 21 days old plants or 4-5 leaf stadia by using an aerosol sprayer. All the leaves of the plants were sprayed thoroughly using the prepared inoculum solution until runoff occurred. Plants in the un-inoculated plots were not inoculated with $D$. oryzae inoculum but instead were regularly sprayed in a weekly interval by using a fungicide Trivia (73 WP) at a concentration of $2 \mathrm{~g} \mathrm{~L}^{-1}$ to prevent the plants from the brown spot.

\section{Observation and data analysis \\ Disease assessment}

The main observed variables included disease severity and grain yield. Disease severity was assessed on ten plants of each rice genotype randomly selected from a sampling area of $1.0 \mathrm{~m}^{2}$ in the middle of each plot and tagged, and the following parameters were observed and recorded: (i) number of leaf per plant, (ii) the disease severity of each leaf in the plant, obtained by comparing the brown leaf severity/symptom on each leaf with the brown leaf spot pictorial scale of IRRI (2013) to obtain the disease score of each leaf. Disease scores of all leaf in each plant were then used to calculate the disease severity of each plant using the formula below:

$$
S=\frac{\sum(n x v)}{Z x N} x 100 \%
$$

Where: $\mathrm{I}=$ disease severity, $\mathrm{n}=$ number of leaves in each disease category/score, $\mathrm{v}=$ disease score, $\mathrm{Z}=$ the highest disease score, $\mathrm{N}=$ total number of leaves observed in each plant. The mean disease severity of each plot was obtained by averaging the disease severities of 10 individual sample plants within each plot.

Assessment of brown spot severity was conducted six times at 35, 42, 49, 56, 63 and 70 days after planting (DAP). At harvest, all the plants within the $1.0 \mathrm{~m}^{2}$ sampling area of each plot were harvested and threshed manually to obtain grain yield per plot $\left(\mathrm{g} \mathrm{plot}^{-1}\right)$ which then converted into yield per hectare $\left(\mathrm{t} \mathrm{ha}^{-1}\right)$ data.

\section{Data analysis}

Brown spot severities over the six recordings were used to calculate the Area Under the Disease Progress Curve (AUDPC) of brown spot following the formula of Campbell and Madden (1990):

$$
\text { AUDPC }=\sum_{i}^{n-1}\left(\frac{Y_{i}+Y_{i+1}}{2}\right)\left(t_{i+1}-t_{i}\right)
$$

Where: $\mathrm{Y}_{\mathrm{i}}=$ disease severity at the $\mathrm{i}^{\text {th }}$ observation, $\mathrm{n}=$ the last disease assessment (number of assessment), $t_{i}=$ time period of assessment at the $\mathrm{i}^{\text {th }}$ observation.
The disease severity at the final recording (70 days after planting), which was about the panicle formation stage was used to assess the resistance level of the rice genotypes based on the standard of IRRI $(2002,2013)$ with disease scale, affected leaf area, and host response/resistant category, respectively, as the followings: (i) No incidence = highly resistant, (ii) less than $1 \%$ affected leaf area = highly resistant, (iii) $1-3 \%$ affected leaf area $=$ resistant, (iv) $4-5 \%$ affected leaf area $=$ resistant, (v) $11-15 \%$ affected leaf area $=$ moderately resistant, (vi) $11-25 \%$ affected leaf area $=$ moderately susceptible, (vii) $26-50 \%$ affected leaf area $=$ susceptible, (viii) $51-75 \%$ affected leaf area = susceptible, (ix) $76-100 \%$ affected leaf area = highly susceptible.

Yield loss was expressed in a relative term as a percentage of yields under diseased plots over yield under disease-free/protected plots following the formula (Ouedraogo et al. 1994; Mau and Ndiwa 2018):

$$
L=\frac{T-U}{T} x 100 \%
$$

Where: $\mathrm{L}=$ yield loss $(\%), \mathrm{T}=$ yield of disease-free plot $\left(\mathrm{kg} \mathrm{ha}^{-1}\right), \mathrm{U}=$ yield $\left(\mathrm{kg} \mathrm{ha}^{-1}\right)$ of diseased plot

Disease severity, AUDPC and yield data were subjected to analysis of variance (ANOVA) and the differences among the genotype means were compared using Duncan's Multiple Range Test at a 5\% significant level. A linear regression analysis was performed to assess the relationship between disease severity and AUDPC with yield under disease conditions and yield loss.

Analysis of variance was performed using Genstat Version 12 (VSNi 2009) software while correlation and regression analysis were performed using PAST (Hammer et al. 2001).

\section{RESULTS AND DISCUSSION}

\section{Disease severity, AUDPC, and resistance level of test genotypes}

Symptoms of brown spot started to appear at three days to seven days after inoculation (or 24-28 days after planting/DAP). Disease severity at 35 DAP ranged from 2$9 \%$, which then increased to $4-12 \%$ at 42 DAP, $7-16 \%$ at 49 DAP, $7-25 \%$ at 56 DAP, 9-32\% at 63 DAP and 11$40.7 \%$ at 70 DAP. Mean disease severity at 70 DAP, AUDPC over six assessments, and resistance level of test genotypes are presented in Table 1.

Table 1 shows that brown leaf spot severities differed significantly among test genotypes. The lowest disease severity was recorded on local cultivars SBR-01 (11.11\%) and PJ-01 (12.42\%) while the highest was observed on local cultivar HK-06 (40.7\%), which did not differ significantly from that of SBD-04 (39.40\%). Fifty percent of test genotypes exhibited disease severities around 11$25 \%$ while the rest $50 \%$ suffered about $26-41 \%$ disease severity. 
Table 1. Disease severity (at 70 DAP), Area Under the Disease Progress Curve (AUDPC), and resistance level of pigmented upland rice genotypes from East Nusa Tenggara, Indonesia.

\begin{tabular}{|c|c|c|c|}
\hline Rice genotypes & $\begin{array}{c}\text { Disease } \\
\text { severity } \\
(\%)^{*}\end{array}$ & $\begin{array}{l}\text { AUDPC } \\
\text { (\%-days) }\end{array}$ & $\begin{array}{c}\text { Resistance } \\
\text { level }^{* *}\end{array}$ \\
\hline ADN-03 & $31.58 \mathrm{jk}$ & $706.53 \mathrm{e}$ & $\mathrm{S}$ \\
\hline ADN-05 & $33.47 \mathrm{kl}$ & $823.58 \mathrm{fg}$ & $\mathrm{S}$ \\
\hline AEK SIBUNDONG & $27.77 \mathrm{~h}$ & 747.08 ef & $S$ \\
\hline $\begin{array}{l}\text { B13784C-MR-2-2- } \\
8-4-1-1-3-3\end{array}$ & $26.32 \mathrm{~h}$ & 695.47 e & $S$ \\
\hline HK-06 & $40.70 \mathrm{o}$ & $843.21 \mathrm{~g}$ & S \\
\hline HK-07 & $33.39 \mathrm{kl}$ & 749.10 ef & S \\
\hline INPAGO 7 & $28.12 \mathrm{hi}$ & $709.64 \mathrm{e}$ & S \\
\hline MANU-04 & $31.18 \mathrm{jk}$ & $803.94 \mathrm{fg}$ & S \\
\hline MGR-04 & $16.90 \mathrm{ef}$ & $576.08 \mathrm{~cd}$ & MS \\
\hline NGR-21 & $31.29 \mathrm{jk}$ & $802.79 \mathrm{fg}$ & $\mathrm{S}$ \\
\hline NGR-22 & $33.41 \mathrm{kl}$ & 762.89 ef & S \\
\hline PAU-01 & $30.34 \mathrm{j}$ & $708.46 \mathrm{e}$ & S \\
\hline PJ-01 & $12.42 \mathrm{ab}$ & $398.42 \mathrm{a}$ & MR \\
\hline PM-01 & $14.60 \mathrm{~cd}$ & $537.70 \mathrm{~cd}$ & MR \\
\hline PMK-01 & $23.90 \mathrm{~g}$ & $595.73 \mathrm{~d}$ & MS \\
\hline SBD-01 & $13.31 \mathrm{bc}$ & $415.02 \mathrm{a}$ & MR \\
\hline SBD-02 & $37.96 \mathrm{mn}$ & $925.91 \mathrm{~h}$ & S \\
\hline SBD-04 & 39.40 no & $1081.30 \mathrm{i}$ & S \\
\hline SBD-05 & $14.80 \mathrm{~cd}$ & $569.21 \mathrm{~cd}$ & MR \\
\hline SBR-01 & $11.11 \mathrm{a}$ & $446.48 \mathrm{ab}$ & MR \\
\hline SLR-07 & $13.20 \mathrm{bc}$ & $505.39 \mathrm{bc}$ & MR \\
\hline TLB-02 & $16.58 \mathrm{de}$ & $403.64 \mathrm{a}$ & MS \\
\hline WTN-21 & $35.52 \mathrm{~lm}$ & $861.68 \mathrm{gh}$ & $\mathrm{S}$ \\
\hline WTN-22 & $18.69 \mathrm{f}$ & $588.14 \mathrm{~d}$ & MS \\
\hline
\end{tabular}

Note: "Data were subjected to Arcsine transformation before ANOVA was carried out. ${ }^{* *}$ Resistance level was determined based on the method of IRRI $(2002,2013)$. MR = moderately resistant, $\mathrm{MS}=$ moderately susceptible, $\mathrm{S}=$ Susceptible. The numbers within the same column with the same letter are not significantly different at 0.05 DMRT.

Mean AUDPC of brown spot was also significantly different among rice genotypes, indicating variability in accumulation of the disease during the observation period. Rice genotypes exhibiting the lowest and the highest total AUDPC were, respectively, PJ-01 (398.42\%-days) and SBD-04 (1081.30\%-days). It is interesting to note that PJ01 and SBD-04, respectively, also showed the lowest and the highest disease severity at the last assessment (70 DAP), indicating that the disease development during the observation period in the two rice genotypes presumably progressed at almost the same rate. Correlation analysis showed that disease severity at 70 DAP was highly significantly correlated $\left(0.93^{* *}\right)$ with AUDPC, thus, either disease severity at 70 DAP or AUDPC can be used as a measure of disease intensity in the test genotypes. The disease severity at 70 DAP was then used to classify the brown spot resistance level of test genotypes based on IRRI (2002, 2013). No resistant genotype was observed on 24 test genotypes but six genotypes (SBR-01, PJ-01, SLR-07, SBD-01, PM-01, SBD-05) were moderately resistant, four genotypes (TLB-02, MGR-04, PMK-01, SBD-01) were moderately susceptible and the rest 14 genotypes were susceptible to brown leaf spot.
Table 2. Yields under diseased-free and diseased plots, and yield loss of pigmented upland rice genotypes from East Nusa Tenggara, Indonesia

\begin{tabular}{|c|c|c|c|}
\hline $\begin{array}{c}\text { Genotype } \\
\text { name/code }\end{array}$ & $\begin{array}{c}\text { Yield }\left(\mathrm{t} \mathrm{ha}^{-1}\right) \text { - } \\
\text { diseased-free } \\
\text { plots }\end{array}$ & $\begin{array}{l}\text { Yield (t ha-1)- } \\
\text { diseased plots }\end{array}$ & $\begin{array}{l}\text { Yield loss } \\
(\%)^{*}\end{array}$ \\
\hline $\mathrm{ADN}-03$ & $3.66 \mathrm{ef}$ & $2.07 \mathrm{~cd}$ & 43.42 fghi \\
\hline ADN-05 & $4.39 \mathrm{~h}$ & $3.12 \mathrm{~g}$ & 28.98 cde \\
\hline AEK SIBUNDONG & $2.76 \mathrm{~b}$ & $1.68 \mathrm{ab}$ & 39.18 defg \\
\hline $\begin{array}{l}\text { B13784C-MR-2-2- } \\
8-4-1-1-3-3\end{array}$ & $3.77 \mathrm{f}$ & $3.33 \mathrm{~g}$ & $11.48 \mathrm{a}$ \\
\hline HK-06 & $5.92 \mathrm{i}$ & $2.80 \mathrm{f}$ & 52.72 hi \\
\hline HK-07 & $6.13 \mathrm{i}$ & $2.69 \mathrm{f}$ & $56.14 \mathrm{i}$ \\
\hline INPAGO 7 & $4.30 \mathrm{gh}$ & $2.74 \mathrm{f}$ & $36.29 \mathrm{def}$ \\
\hline MANU-04 & $4.24 \mathrm{gh}$ & $2.31 \mathrm{de}$ & 45.13 fghi \\
\hline MGR-04 & $3.37 \mathrm{~d}$ & $2.33 \mathrm{de}$ & 30.54 cde \\
\hline NGR-21 & $2.89 \mathrm{bc}$ & $1.42 \mathrm{ab}$ & 50.95 ghi \\
\hline NGR-22 & $4.27 \mathrm{gh}$ & $2.60 \mathrm{ef}$ & 39.16 defg \\
\hline PAU-01 & $3.51 \mathrm{de}$ & $2.30 \mathrm{de}$ & 34.42 cdef \\
\hline PJ-01 & $4.22 \mathrm{gh}$ & $3.74 \mathrm{~h}$ & $11.36 \mathrm{a}$ \\
\hline PM-01 & $2.98 \mathrm{bc}$ & $2.14 \mathrm{~cd}$ & $27.95 \mathrm{~cd}$ \\
\hline PMK-01 & $4.33 \mathrm{gh}$ & $2.55 \mathrm{ef}$ & 41.14 efgh \\
\hline SBD-01 & $2.26 \mathrm{a}$ & $1.71 \mathrm{ab}$ & $24.41 \mathrm{bc}$ \\
\hline SBD-02 & $3.84 \mathrm{f}$ & $1.69 \mathrm{ab}$ & $56.15 \mathrm{i}$ \\
\hline SBD-04 & $4.13 \mathrm{~g}$ & $2.21 \mathrm{~cd}$ & 46.45 fghi \\
\hline SBD-05 & $2.34 \mathrm{a}$ & $1.95 \mathrm{bc}$ & $16.54 \mathrm{ab}$ \\
\hline SBR-01 & $2.95 \mathrm{bc}$ & $2.58 \mathrm{ef}$ & $12.52 \mathrm{a}$ \\
\hline SLR-07 & $3.47 \mathrm{de}$ & $3.11 \mathrm{~g}$ & $10.46 \mathrm{a}$ \\
\hline TLB-02 & $3.36 \mathrm{~d}$ & $2.79 \mathrm{f}$ & $16.73 \mathrm{ab}$ \\
\hline WTN-21 & $3.83 \mathrm{f}$ & $1.69 \mathrm{ab}$ & $55.91 \mathrm{i}$ \\
\hline WTN-22 & $3.08 \mathrm{c}$ & $1.96 \mathrm{bc}$ & 36.37 def \\
\hline
\end{tabular}

Note: Numbers within the same column with the same letter are not significantly different at 0.05 DMRT. "Data were subjected to Arcsine transformation before ANOVA was carried out.

\section{Yield and yield loss of test genotypes}

Yield of each test genotype was obtained from the conversion of dry (12\% moisture content) grain yield of rice plants within one square meter sampling area of each plot into yield per hectare. The disease severities of test genotypes under disease-free/protected plots were negligible, ranging from $2-5 \%$ at $70 \mathrm{DAP}$, thus, the grain yields were directly converted into yield per hectare without any correction. A range of grain yield between $2.34 \mathrm{t} \mathrm{ha}^{-1}$ to $6.13 \mathrm{t} \mathrm{ha}^{-1}$ was observed in the diseased-free plots while that in the diseased plots fell into 1.68-3.74 $\mathrm{t} \mathrm{ha}^{-}$ ${ }^{1}$. In diseased-free plot, yields differed significantly among genotypes, indicating their variability in yield potential. A similar condition holds for plants grown under diseased plots, which may indicate variability in both yield potential and yield response under brown spot disease condition.

Local cultivars HK-07 (6.13 $\left.\mathrm{t} \mathrm{ha}^{-1}\right)$ and HK-06 (5.92 t $\mathrm{ha}^{-1}$ ) produced the highest yields under diseased-free conditions while PJ-01 (3.74 $\left.\mathrm{t} \mathrm{ha}^{-1}\right)$ produced the highest yield under disease condition. Similarly, genotype producing the lowest grain yield under diseased-free condition (SBD-05) was also different from that under diseased condition (NGR-21). This indicates that the test genotypes have different yield potential, and their yields under diseased conditions might have been determined by factors that influence their yield potential as well those affecting their yield response under diseased conditions. 
Variability in yield under diseased-free and diseased conditions ultimately caused brown spot-inducing yield loss to be greatly varied. The yield loss on the test genotypes differed significantly, ranging from $10.46 \%$ to $56.15 \%$ (Table 2). The genotypes exhibiting the lowest yield loss are mostly those suffering the lowest disease severity $(<15 \%)$, which are categorized as moderately resistant genotypes, i.e., SLR-07, SBR-01, and PJ-01, but more interestingly, the brown spot susceptible genotype B13784C-MR-2-2-8-4-1-1-3-3 with much higher disease severity $(26.32 \%)$ was also among the genotypes showing the lowest yield loss $(11.48 \%)$. The test genotypes demonstrating the highest yield loss $(>45 \%)$, i.e., SBD-02, HK-07, WTN-21, HK-06, SBD-04, NGR-21, MANU-04, are those suffering high disease severity $(>30 \%)$ and AUDPC (>700\%-days), and were classified susceptible based on IRRI standard (IRRI 2002, 2013).

Classification of brown spot disease severity in relation to yield loss is shown in Figure 1. The increase in disease severity was not consistently followed by an increase in yield loss (Figure 1). Of the six genotypes with lower disease severity (moderately resistant/MR category), four genotypes had the lowest yield loss $(<15 \%)$ while two other genotypes suffered a much higher $(>20 \%)$ yield loss, approaching those of moderately susceptible genotype MGR-04 (MS-9) and susceptible genotype ADN-05 (S-2). Figure 1 also shows that on the genotypes of susceptible category, the increase in disease severity tended to be followed by an increase in yield loss but the magnitude of yield loss increase was not proportionate to the increasing level of disease severity, indicating differential yield loss response of the genotypes against the brown spot disease. More interestingly, the susceptible genotype B13784CMR-2-2-8-4-1-1-3-3 suffered a much lower yield loss $(11.48 \%)$, similar to those of the four moderately resistant genotypes. Thus, these findings indicate that, under this upland rice germplasm genetic diversity level, yield loss is not only determined by brown spot disease severity or brown spot resistance level but also by other factors that might have influenced the yield of the test genotypes under brown spot disease condition. These additional factors may include tolerance to brown spot disease. Tolerance to disease is the ability of a crop to produce good yield under the presence of substantial disease severity (Schafer 1971; Agrios 2004). The susceptible genotype B13784C-MR-2-28-4-1-1-3-3 could still produce high yield despite its high disease severity (Table 2, Figure 1), which may indicate disease tolerance.

\section{Relationships between disease severity and yield and yield loss}

Regression analysis results, as shown in Figure 2, reveal that neither disease severity (at 70 DAP) nor AUDPC had a significant relationship with yields of test genotypes. A coefficient determination of 0.0358 (Figure 2a) indicates that disease severity contributed only about $3.58 \%$ to the observed variation in yield of the test genotypes, and the rest of the variation was contributed by other factors. Similarly, AUDPC contributed only about $8.33 \%$ (Figure $2 \mathrm{~b}$ ) to the observed yield variation.

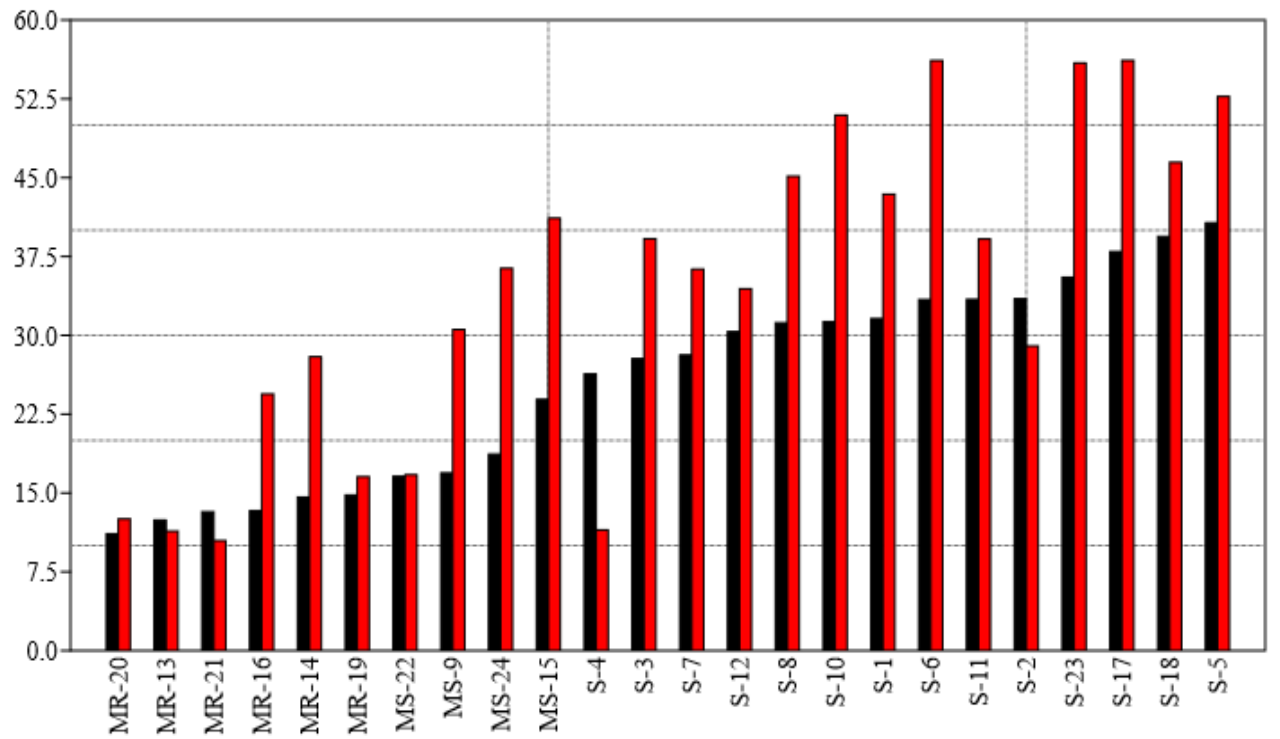

Figure 1. Resistance level and yield loss of test genotypes of pigmented upland rice cultivars from East Nusa Tenggara Province, Indonesia. $M R=$ Moderately Resistant, $M S=$ Moderately Susceptible, $S=$ Susceptible. $1-24$ = genotype number: $1=A D N-03,2=A D N-05$, 3=AEK SIBUNDONG, 4=B13784C-MR-2-2-8-4-1-1-3-3, 5=HK-06, 6=HK-07, 7=INPAGO 7, 8=MANU-04, 9=MGR-04, 10=NGR21, 11=NGR-22, 12= PAU-01, 13=PJ-01, 14=PM-01, 15=PMK-01, 16=SBD-01, 17=SBD-02, 18=SBD-04, 19=SBD-05, 20=SBR-01, $21=$ SLR-07, 22=TLB-02, 23=WTN-21, 24=WTN-22. 
The present study finding is in contrast to the previous finding where disease severity and/or AUDPC were found to have a significant linear relationship with grain yield of test genotypes (Pantha et al. 2017). Lack of significant linear relationship between disease severity and AUDPC with yield in the present study may have been caused by many factors such as variability in yield potential, brown spot resistance level, and yield response to brown spot disease of the test genotypes. These variations are partly depicted in Figure 2, where genotype number 4 (B13784CMR-2-2-8-4-1-1-3-3) and 2 (ADN-05) were still producing high yield $\left(>3 \mathrm{t} \mathrm{ha}^{-1}\right)$ despite their high disease severity and AUDPC, while genotype number 16 (SBD-01), 19 (SBD05), 24 (WTN-22) produced only below $2 \mathrm{t} \mathrm{ha}^{-1}$ grain yield although they suffered only a low level of disease severity. Additional variation in yield response of other genotypes made the assumed linear relationship between disease severity or AUDPC with yields of test genotypes negligible.

In contrast to its relationship with yield, disease severity was found to have a positive and linear relationship with yield loss (Figure 3.A). A determination coefficient of 0.6713 indicates that about $67.13 \%$ of the variation in yield loss of test genotypes can be explained by variation in disease severity. A similar situation holds for AUDPC and yield loss, where a positive and linear relationship between the two variables was also observed with $58.61 \%$ of the observed variation in yield loss being explained by AUDPC variation (Figure 3.B). Previous studies (Schafer 1971; Kramer et al. 1980; Parker et al. 2004) highlighted that the relationship between yield loss and disease severity can differ widely between crop genotypes.

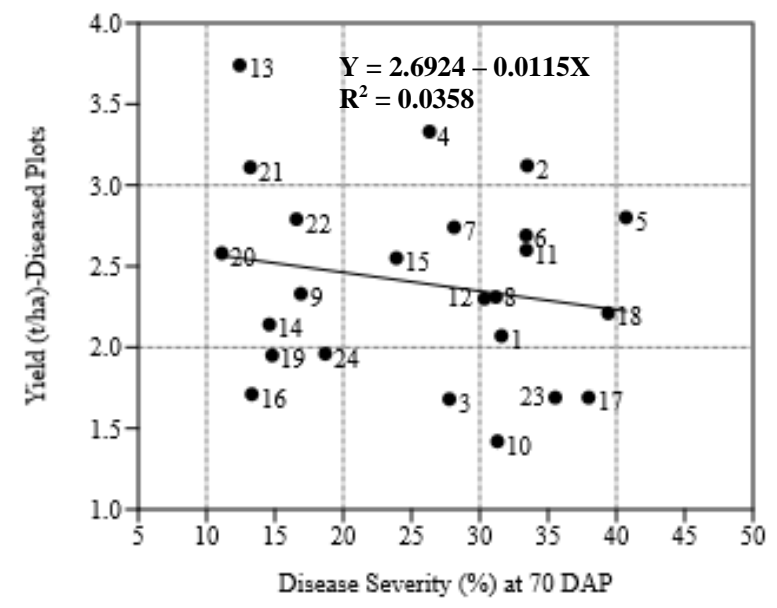

A
Despite their linear relationships with yield loss, there are still quite high percentages of observed variation of yield loss that cannot be explained by disease severity (32.87\%) and AUDPC (41.39\%). This phenomenon can be partly explained by the presence of some outliers in Figure 3. Genotype number 4 (Figure 3a) seems to largely deviate from other genotypes as it suffered a high disease severity but experienced only a minor yield loss. The same situation was found in Figure 3b, where genotype number 4 also behaved differently from other genotypes; it had a high AUDPC but suffered a low yield loss. The higher unexplainable yield variation by AUDPC as compared to that of disease severity, was also contributed by genotypes 2 and 18, which also behaved almost the same manner as genotype 4 .

\section{Discussion}

The present study results demonstrated varying responses of pigmented upland rice cultivars to brown leaf spot. Similar results have previously been observed in white-lowland rice by several studies (Percich et al.1997; Hossain and Kulkarni 2001; Magar 2015; Pantha et al. 2017). Using the same disease severity rating scale (IRRI $2002)$, the disease severity (11.11-40.70\%) and total AUDPC (398.42-1081.30\%-days) ranges of the present study were a bit lower than that observed by Magar (2015), who recorded disease severity and AUDPC value ranges of, respectively, 21.73- 58.07\% and 614.8-1827\%-days. These differences presumably occurred due to different rice genotypes being tested ( 24 genotypes in this study and 14 genotypes in the study by Magar (2015) since different genotypes will have a different reaction to brown spot disease.

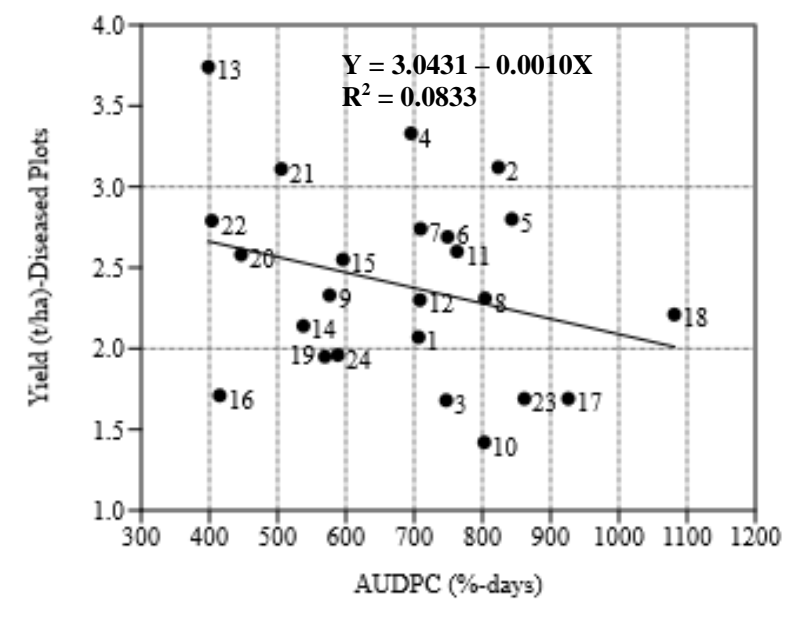

B

Figure 2. Relationships between disease severity (A) and AUDPC (B) with yield of tested pigmented upland rice genotypes from East Nusa Tenggara, Indonesia. 1 - 24 = genotype number: 1=ADN-03, 2=ADN-05, 3=AEK SIBUNDONG, 4=B13784C-MR-2-2-8-4-1-1-33, 5=HK-06, 6=HK-07, 7=INPAGO 7, 8=MANU-04, 9=MGR-04, 10=NGR-21, 11=NGR-22, 12= PAU-01, 13=PJ-01, 14=PM-01, 15=PMK-01, 16=SBD-01, 17=SBD-02, 18=SBD-04, 19=SBD-05, 20=SBR-01, 21=SLR-07, 22=TLB-02, 23=WTN-21, $24=\mathrm{WTN}-22$. 


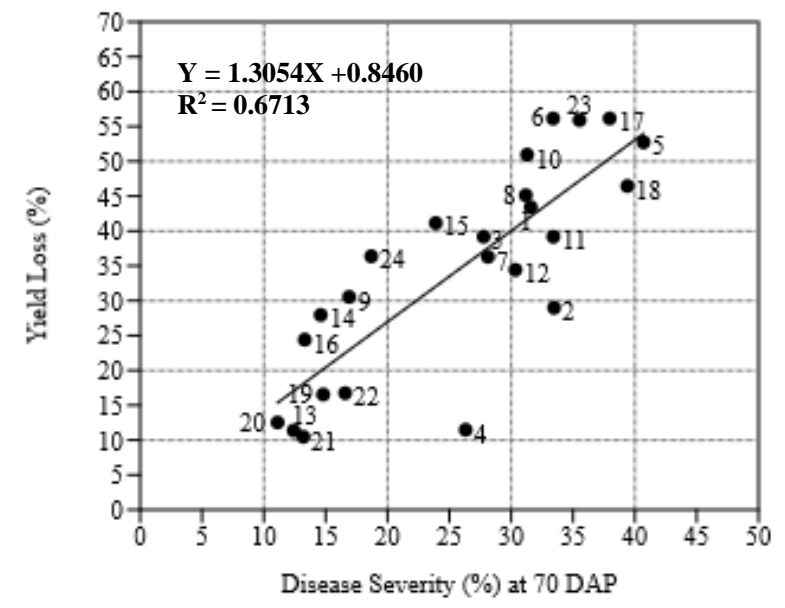

A

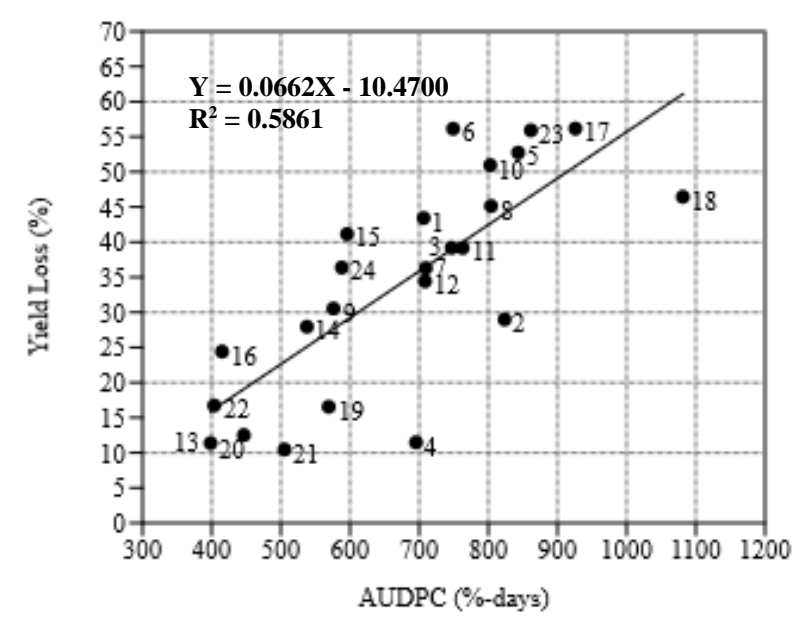

B

Figure 3. Relationships between disease severity (A) and AUDPC (B) with yield loss of tested pigmented upland rice genotypes from East Nusa Tenggara, Indonesia. 1 - 24 = genotype number: 1=ADN-03, 2=ADN-05, 3=AEK SIBUNDONG, 4=B13784C-MR-2-2-8-41-1-3-3, 5=HK-06, 6=HK-07, 7=INPAGO 7, 8=MANU-04, 9=MGR-04, 10=NGR-21, 11=NGR-22, 12= PAU-01, 13=PJ-01, 14=PM01, 15=PMK-01, 16=SBD-01, 17=SBD-02, 18=SBD-04, 19=SBD-05, 20=SBR-01, 21=SLR-07, 22=TLB-02, 23=WTN-21, 24=WTN22

In addition to genotypic differences, the difference in total AUDPC might have happened due to difference in number of disease assessments carried out as total AUDPC is the accumulation of all the recorded disease severity during the experimental period. A study by Percich et al. (1997) found that the infection efficiency of pathogen increased with an increase in temperature, humidity, and moisture. Also, Magar (2015) stated that inoculum pressure and favorable conditions in the field might have caused an increase in AUDPC value of even resistant genotypes in the field. Thus, variability in environmental conditions under which the crops were grown may have also contributed to the observed differences in both disease severity and AUDPC of the present study and those of previous studies.

Brown spot resistant genotype was lacking in the present study while six moderately resistant genotypes were identified out of total 24 test genotypes. Similar to this study, Magar (2015) observed no brown spot resistant genotype, and only two moderately resistant varieties were identified from 14 low lowland rice varieties evaluated. Arshad et al. (2008) found only one entry among seventy entries was resistant against brown leaf spot. Conversely, out of 20 genotypes examined, Pantha et al. (2017) identified one highly resistant, two resistant and 10 moderately resistant genotypes. Six highly resistant and three resistant lines were found by Jha et al. (1999) among fifty rice accession lines examined. Besides, Goel et al. (2006) obtained 15 resistant and 78 moderately resistant lines out of 219 wild rice accessions, and Omar (1979) identified 26 japonica and indica rice genotypes that were resistant to brown spot at all stages. Out of 124 Oryza sativa entries evaluated by Satija et al. (2005), 15 entries were found resistant to brown spot, while Hossain et al. (2004) identified only one resistance out of 29 lines evaluated. Partial and complete resistance to brown spot was found to be expressed by several upland rice genotypes of eastern India (Shukla et al. 1995). Differences in the number of resistant and moderately resistant genotypes identified in different studies may occur due to different levels of genetic diversity of the germplasm and number of genotypes being evaluated. As true resistance is controlled by the genetic factor (Agrios 2004), thus, different germplasm being evaluated will ultimately result in different numbers of resistant genotypes.

Resistance to rice brown spot does occur through various mechanisms. Ou (1985) found that some anatomical characters such as thicker epidermal cells and more silicated cells were positively correlated with resistance, but this was in contrast to another study by Purkayastha and Chattopadhyay (1975) who found no correlation between anatomical characters of rice plants with brown spot resistance. Additionally, stimulated synthesis of polyphenols and their oxidation products were observed to be correlated with resistance (Oku 1965; Ou 1985). A coincidence of increased susceptibility to brown spot and increased dry weight, free amino acids, total nitrogen, and total protein was reported by Ou (1985). Oku (1965) suggested that glutathione or ascorbic acid, both are reducing agents, may contribute to disease resistance. Differential resistance levels and the number of resistance genotypes observed in the present study and those of previous studies may reflect variation in resistance mechanism presents in tested rice genotypes.

Yields of test genotypes in this study varied significantly ranging from, respectively, 2.34-6.13 $\mathrm{t} \mathrm{ha}^{-1}$ in the diseased-free plots and 1.68-3.74 $\mathrm{t} \mathrm{ha}^{-1}$ in the diseased plots. Genotypes producing the highest yield $\left(>5 \mathrm{t} \mathrm{ha}^{-1}\right)$ under diseased-free plots, could produce only below $3 \mathrm{t} \mathrm{ha}^{-1}$ yield under diseased plots, indicating high yield loss. Variation in yield under diseased-free condition may be due to differential yield potential, but variation in yield 
under diseased condition presumably because the test genotypes had both different yield potential as well as yield response under disease stress. We found in this study that increases in disease severity tended to reduce yield, and hence increased yield loss. This is because the brown spot lesions will reduce the leaf photosynthetic area and the efficient use of nutrients, which in turn reduces the yield of diseased plants (Kranz et. al. 1978; Lee 1992; Mew and Gonzales 2002; IRRI 2009; Pantha 2017). Also, infection by $D$. oryzae was reported to cause a decline in yield by increasing the number of un-filled grains, reducing the number of grains per panicle and grain weight (Sanchote and Van Ba 2005).

This study showed that the degree of increase of yield loss was not proportionate to an increased level of disease severity, as there were a few genotypes that suffered high disease severity (susceptible category) but experienced low yield loss similar to that of moderately resistant genotypes. Genotypes that are able to produce good yield under high disease severity can be considered as tolerant to disease (Schafer 1971; Agrios 2004). Similar disease tolerance had also been identified by Magar (2015) on HJ-G1 variety that had the highest grain yield of $5.10 \mathrm{t} \mathrm{ha}^{-1}$ despite its moderate disease severity $(21.73 \%)$ and high total AUDPC value (6148). The mechanisms underlying disease tolerance of crops is poorly understood at present (Bingham and Topp 2009) but in cereal crops, several traits have been proposed to potentially influence the tolerance to foliar disease, which included those related to the preservation of radiation interception, radiation use efficiency (RUE), or partitioning of biomass to harvestable parts (harvest index) in infected plants (Parker et al. 2004; Bingham et al. 2009). Crop genotypes with large canopy area, for instance, may confer tolerance to foliar diseases since reductions in healthy leaf area may have less effect on radiation interception as compared to those with a smaller canopy area (Bingham and Topp 2009). Additionally, crop genotypes that can increase the rate of photosynthesis in the healthy tissue of diseased leaves could be tolerant to foliar diseases by compensating for the loss of healthy tissue and therefore, maintaining good yield (Rooney and Hoad 1989; Murray and Walters 1992; Zuckerman et al. 1997; Bingham et al. 2009). The existence of presumed disease tolerance, in this case, could be considered as a complementary strategy to the disease management as, in case the disease epidemics cannot be fully controlled, it will minimize the impact of the disease on yield (Newton 2016).

The results showed no significant relationship between either disease severity or AUDPC with yield of test genotypes, which is contradictory to the findings of Pantha et al. (2017), where brown spot severity and AUDPC had a negative and significant relationship with grain yield of test genotypes. This difference may have happened due to the different germplasm evaluated, which may possess different levels of genetic diversity. Absence of significant linear relationships between disease severity and AUDPC with yield in this study can be partly explained by the scattered distribution of yield under varying levels of disease severity and AUDPC (Figure 3), where genotypes of almost similar resistance level (disease severity and AUDPC) produced significantly different yields. Thus, the absence of a significant linear relationship may be due to variability in yield potential and yield response of test genotypes under brown spot disease condition.

Either disease severity or AUDPC had a positive and significant linear relationship with yield loss of test genotypes. However, the disease severity and AUDPC could explain the observed variation of yield loss by only, respectively, $67.13 \%$ and $58.61 \%$, leaving the rest $32.87 \%$ and $41.39 \%$ of observed yield loss variation unexplainable. The presence of genotypes deviated significantly from the other genotypes in terms of yield loss and disease severity or AUDPC, i.e., those still producing good yield in spite of high disease severity or AUDPC (genotype number 4 and 2), presumably contributed to the rest un-explainable variation of yield loss of test genotypes. The crop genotypes that showed a smaller yield reduction under high disease severity are considered to be more tolerant of disease (Agrios 2004; Parker et al. 2004; Foulkes et al. 2006; Inglese \& Paul 2006; Bingham and Newton 2009).

Overall, the present study results, as compared to findings of the previous studies, imply that the relationships between brown spot disease severity or AUDPC with yield and yield loss of genotypes with varying levels of susceptibility are very much dependent on the level of genetic diversity that exists in the germplasm being evaluated. Although disease severity or AUDPC had been frequently found to be linearly related to yield and yield loss of various crops (Pataky et al. 1998; Bassanezi et al. 2011; Chuwa et al. 2015; Pantha et al. 2017; Mau and Ndiwa 2018), the existence of genotypes with unusual behaviors such as the presumed tolerance as found in this study may disturb the commonly found linear relationship. Thus, this kind of relationship must be established for each gene pool assuming that each gene pool has a different level of genetic diversity.

Of the six moderately resistant genotypes identified in this study, four genotypes (PJ-01, SBD-01, SBD-05, SBR01) were also found by Mau et al. (2018) to be resistant and moderately resistant to single or two races of Pyricularia grisea (the causal pathogen of rice blast disease). The cultivar PJ-01 also produced the highest yield $\left(3.74 \mathrm{t} \mathrm{ha}^{-1}\right)$ under the diseased condition of the present study. More interestingly, the other moderately-resistant cultivar SLR07 (3.11 $\mathrm{t} \mathrm{ha}^{-1}$ yield in diseased plots) has also been previously found to be highly resistant or resistant to multiple races of $P$. grisea (Mau et al. 2018). Thus, genotypes with moderate resistance level and high yielding under diseased conditions hold a great promise as a genetic resource for the development of high yielding, multiple disease-resistant varieties. Genotype B13784C-MR-2-2-84-1-1-3-3 which also produced high yield (3.33 $\mathrm{t} \mathrm{ha}^{-1}$ ) under high disease severity, and was presumed to show disease tolerance in this study, may also serve as a choice for farmers in tackling the brown spot disease while maintaining a high yield.

In conclusion, the present study results revealed significant variation in brown spot severity and AUDPC, 
ranging from, respectively, $11.11 \%$ to $40.70 \%$ and $398.42 \%$-days to $1081.30 \%$-days. Yields and yield losses of test genotypes also varied substantially. Yields under diseased-free and diseased plots ranged from, respectively, $2.34 \mathrm{t} \mathrm{ha}^{-1}$ to $6.13 \mathrm{t} \mathrm{ha}^{-1}$ and $1.68 \mathrm{t} \mathrm{ha}^{-1}$ to $3.74 \mathrm{t} \mathrm{ha}^{-1}$ while yield loss was between $10.46 \%$ and $56.15 \%$. Six genotypes were moderately resistant; four genotypes were moderately susceptible and 14 genotypes were susceptible to brown spot. Neither disease severity nor AUDPC had a linear relationship with yield but both exhibited positive and linear relationships with yield loss.

\section{ACKNOWLEDGEMENTS}

We are grateful to the Directorate of Research and Community Services (DRPM) of the Indonesian Ministry of Research, Technology and Higher Education for supporting this research through Penelitian Terapan Unggulan Perguruan Tinggi research scheme, the financial year 2019 (Contract Number: 41/UN15.19/LT/2019). Our thanks and high appreciation are extended to Kartika M. Nalle, Lazarus Oematan, Theresia R. Rosari and Novatsiana A. Doko for the great assistance they provided during the research in the laboratory and the field.

\section{REFERENCES}

Agarwal VK. 1989. A simpler technique for routine examination of rice seed lots for rice brown leaf spot disease. Seed Technology News. Bull Indian Soc Seed Technol 11: 1-2.

Agrios GN. 2004. Plant Pathology. $5^{\text {th }}$ ed. Elsevier Academic Press, London, UK

Aluko MO. 1975. Crop losses caused by brown leaf spot disease of rice in Nigeria. Plant Dis Rep 59: 609-613.

Arshad HMI, Khan JA, Jamil FF. 2008. Screening of rice germplasm against blast and brown spot diseases. Pak J Phytopathol 20 (1): 52 57.

Aryal L, Bhattarai G, Subedi A, Subedi M, Subedi B, Sah GK. 2016. Response of rice varieties to brown spot disease of rice at Paklihawa, Rupandehi. Glob J Biol Agric Health Sci 5 (2): 50-54.

Asghar A, Rashid H, Ashraf M, Khan MH, Chaudry AZ. 2007. Improvement of basmati rice against fungal infection through gene transfer technology. Pak J Bot 39 (4): 1277-1283.

Asghar M, Baig MMQ, Chaudhary S, Iqbal MF, Ali MA. 2019 Evaluation of difenoconazole along with macronutrients spray for the control of brown leaf spot (Bipolaris oryzae) disease in rice (Oryza sativa) crop. Sarhad J Agriculture 35 (1): 1-6.

Barnwal MK, Kotasthane A, Magculia N, Mukherjee PK, Savary S, Sharma AK, Singh HB, Singh US, Sparks AH, Variar M, Zaidi N 2013. A review on crop losses, epidemiology and disease management of rice brown spot to identify research priorities and knowledge gaps. Eur J Plant Pathol 136: 443-457. DOI: 10.1007/s10658-013-0195-6.

Bassanezi RB, Montesino LH, Gasparoto MCG, Filho AB, Amorim L. 2011. Yield loss caused by huanglongbing in different sweet orange cultivars in São Paulo, Brazil. Eur J Plant Pathol 130: 577-586. DOI 10.1007/s10658-011-9779-1.

Bingham IJ, Topp CFE. 2009. Potential contribution of selected canopy traits to the tolerance of foliar disease by spring barley. Plant Patho 58: 1010-1020. DOI: 10.1111/j.1365-3059.2009.02137.x

Bingham IJ, Walters DR, Foulkes MJ, Paveley ND. 2009. Crop traits and the tolerance of wheat and barley to foliar disease. Ann Appl Biol 154: 159-173. DOI: 10.1111/j.1744-7348.2008.00291.x

Chattopadhyay SB, Chakravarti NK, Ghose AK. 1975. Estimation of loss in yield of rice due to infection of brown spot incited by Helminthosporium oryzae. Phytopathol 50: 434-438.
Chuwa CJ, Mabagala RB, Reuben MSOW. 2015. Assessment of grain yield losses caused by rice blast disease in major rice-growing areas in Tanzania. Intl J Sci Res 4 (10): 2211-2218.

Cortesi P, Guiditta L. 2003. Epidemics and disease management of rice brown spot and rice blast in Italy. Inf Fitopatol 53: 41-51.

Dallagnol LJ, Rodrigues FÁ, Mielli MVB, Ma JF, Datnoff L E. 2009. Defective active silicon uptake affects some components of rice resistance to brown spot. Phytopathol 99: 116-121.

Datnoff LE, Lentini RS. 2003. Brown spot in Florida Rice. IFAS Extension, University of Florida, Miami, FL.

Fomba SN, Singh N. 1990. Crop losses caused by brown spot disease in mangrove swamps of North Sierra Leone. Trop Pest Manag 36: 387393.

Foulkes MJ, Paveley ND, Worland A, Welham SJ, Thomas J, Snape JW. 2006. Major genetic changes in wheat with potential to affect disease tolerance. Phytopathol 96: 680-688.

Goel RK, Bala R, Sing K. 2006. Genetic characterization of resistance to brown leaf spot caused by Drechslera oryzae in some wild rice (Oryza sativa) lines. Indian J Agric Sci 76 (11): 705-707.

Hammer $\varnothing$, Harper DAT, Ryan PD. 2001. PAST: paleontological statistics software package for education and data analysis. http: //palaeo-electronica.org/2001_1/past/issue1_01.htm. [Accessed: 2610-2019].

Haq IM, Adnan MF, Jamil FF, Rehman A. 2002. Screening of rice germplasm against Pyricularia oryzae and evaluation of various fungitoxicants for control of disease. Pakistan J Phytopathol (1): 3235 .

Hau FC, Rush MC. 1980. A system for inducing sporulation of Bipolaris oryzae. Plant Dis 64: 788-789.

Hossain MM, Kulkami S. 2001. Field evaluation of fungicides, neembased formulations and biological agents against blast of rice. $\mathrm{J}$ Maharashtra Agric Univ 26 (1-3): 148-150.

Hossain M, Khalequzzaman KM, Mollah M RA, Hussain MA, Rahim MA. 2004. Reaction of breeding lines/cultivars of rice against brown spot and blast under field condition. Asian J Plant Sci 3: 614-617.

Inglese SJ, Paul ND. 2006. Tolerance of Senecio vulgaris to infection and disease caused by native and alien rust fungi. Phytopathol 96: 718-26.

IRRI. 2002. Standard Evaluation System for Rice. International Rice Research Institute (IRRI), Los Banos. Philippines.

IRRI. 2009. Brown Spot (Rice Facts Sheet). International Rice Research Institute, Los Banos, Philippines.

IRRI. 2012. Rice Facts. International Rice Research Institute, Los Banos, Philippines.

IRRI. 2013. Standard Evaluation System for Rice. $5^{\text {th }}$ ed. International Rice Research Institute (IRRI), Manila, Philippines.

Jha AC, Mishra MM, Jha MM. 1999. Reaction of rice accessions to Drechslera oryzae causing brown spot under deep water ecosystem. J Appl Biol 9: 64-66.

Jha AC. 2001. Development and management brown spot of rice caused by Drechslera oryzae (Breda de Haan) Subramanian and Jain. [Dissertation]. RAU Bihar, Pusa, Samastipur, India.

Katasntones G, Koutrovbas S.D, Ntanos DA, Lupoho E. 2007. A comparison of three experimental designs for the field assessment of resistance to rice brown leaf spot of rice disease (Bipolaris oryzae). J Phytopath 155: 204-210.

Kramer T, Gildemacher BH, Van Der Ster M, Parlevliet JE. 1980. Tolerance of spring barley cultivars to leaf rust, Puccinia hordei. Euphytica 29: 209-16.

Kranz J, Schmutterer H, Kock W. 1978. Diseases, Pests and Weeds in Tropical Crops. John Wiley and Sons Ltd. Toronto.

Lee FN. 1992. Brown spot. In: Webster RK, Gunnell PS (eds.). Compendium of Rice Diseases. The American Phytopathological Society, St. Paul, MN.

Lenz G, Balardin RS, Corte GD, Marques LN, Debonal D. 2010. Diagrammatic scale for assessment of rice brown spot severity. Ciencia Rural 40 (4): 752-758. DOI: 10.1590/S010384782010005000061 .

Mandal SK, Jha VB. 2008. Management of foliar disease of rice through fungicides. Ann. Plant Prot. Sci. 16: 523 - 525

Magar PB. 2015. Screening of rice varieties against brown leaf spot disease at Jyotinagar, Chitwan, Nepal. Intl J Appl Sci Biotechnol 3 (1): 56-60.

Mau YS, Ndiwa AS, 2018. Field evaluation of late leaf spot and leaf rust resistance and the associated yield losses in Indonesian groundnut genotypes. Asian J Plant Sci 17 (3): 134-141. DOI: 10.3923/ajps.2018.134.141 
Mau YS, Ndiwa AS, Markus JER, Oematan SS, Nasution A, Handoko DD, Makbul K. 2018. Blast resistance levels of red and black upland rice local cultivars from Indonesia. Asian J Crop Sci 10 (2): 53-65. DOI: 10.3923/ajcs.2018.

Mew TW, Gonzales P. 2002. A Handbook of Rice seed borne fungi. Las Banos, Laguna, Philippines.

Murray D, Walters DR. 1992. Increased photosynthesis and resistance to rust infection in upper, uninfected leaves of rusted broad bean (Vicia faba L.). New Phytol 120: 235-242. DOI: 10.1111/j.14698137.1992.tb05659.x.

Newton AC. 2016. Exploitation of diversity within crops - the key to disease tolerance? Front Plant Sci 7: 665. DOI $10.3389 /$ fpls.2016.00665.

Nneke NE. 2012. Screening lowland rice varieties for resistance to brown spot disease in Enyong creek rice field in Akwa Ibom state of Nigeria. Glob J Pure Appl Sci 18 (1\&2): 5-10.

Ouedraogo M., O.D. Smith, C.E. Simpson and D.H. Smith, 1994. Early and late leaf spot resistance and agronomic performance of nineteen interspecific derived peanut lines. Peanut Sci 21: 99-104.

Ou SH. 1985. Rice Diseases, $2^{\text {nd }}$ ed. Commonwealth Mycological Institute, Kew, U.K.

Oku H. 1965. Host-parasite relationship in Helminthosporium leaf spo disease of rice plant. Rep Takamine Lab 17: 35-56.

Omar RA, Balal MS, El-Kazzaz MK, Aidy IR. 1979. Reaction of rice varieties to the brown spot disease of rice, Cochliobolus miyabeanus, at different stages of growth. Agric Res Rev 57: 103-118

Padmanabhan SY. 1973. The great Bengal famine. Ann Rev Phytopathol 11: 11-26. DOI: 10.1146/annurev.py.11.090173.000303.

Pantha P, Shrestha SM, Manandhar HK, Gaire SP, Aryal L, Yadav DR. 2017. Evaluation of rice genotypes for resistance against brown spo disease caused by Bipolaris oryzae. Intl J Curr Res 9 (4): 48562 48569 .

Parker SR, Welham S, Paveley ND, Foulkes J, Scott RK. 2004. Tolerance of septoria leaf blotch in winter wheat. Plant Pathol 53: 1-10.

Pataky JK, Raid RN, du Toit LJ, Schueneman TJ. 1998. Disease severity and yield of sweet corn hybrids with resistance to northern leaf blight. Plant Dis 82: 57-63.

Percich JA, Nyvall RF, Malvick DK, Kohls CL. 1997. Interaction of temperature and moisture on infection of wild rice by Bipolaris oryzae in the growth chamber. Plant Dis 8 (10): 1193-1195.

Purkayastha RP, Chattopadhyay M. 1975. Studies on the resistance of rice cultivars to helminthosporiose. Indian Phytopath 28: 33-37.

Reddy CS, Laha GS, Prasad MS, Krishnaveni D, Castilla NP, Nelson A Savary S. 2011. Characterizing multiple linkages between individual diseases, crop health syndromes, germplasm deployment and rice production situations in India. Field Crops Res 120 (2): 241-253.

Rooney JM, Hoad GV. 1989. Compensation in growth and photosynthesis of wheat (Triticum aestivum L.) following early inoculations with Septoria nodorum (Berk.) Berk. New Phytol 113: 513-521. DOI: 10.1111/j.1469-8137.1989.tb00363.x
Sanchote S, Van Ba V. 2005. Seed borne and transmission of Bipolaris oryzae, the causal pathogen of brown spot of rice. In: Proceedings of 43rd Kasetsart University Annual Conference, Thailand, 1-4 February 2005.

Satija A, Chahal SS, Pannu P PS. 2005. Evaluation of rice genotypes against brown leaf spot disease. Plant Dis Res (Ludhiana) 20: 163164.

Sato H, Ando I, Hirabayashi H, Takeuchi Y, Arase S, Kihara J, Kato H, Imbe T, Nemoto H. 2008. QTL analysis of brown spot resistance in rice (Oryza sativa L.). Breed. Sci 58: 93-96. DOI: $10.1270 /$ jsbbs. 58.93

Savary S, Castilla NP, Elazegui FA, Teng PS. 2005. Multiple effects of two drivers of agricultural change, labour shortage and water scarcity, on rice pest profiles in tropical Asia. Field Crops Res 91: 263-271. DOI: 10.1016/j.fcr.2004.07.017.

Savary S, Willocquet L, Elazegui FA, Castilla N, Teng PS. 2000. Rice pest constraints in tropical Asia: quantification of yield losses due to rice pests in a range of production situations. Plant Dis 84: 357-369.

Schafer JF. 1971. Tolerance to plant disease. Ann Rev Phytopathol 9: 235-252. DOI: 10.1146/annurev.py.09.090171.001315

Shukla VD, Chauhan JS, Variar M, Maiti D. Chauhan VS, Tomar JB. 1995. Reaction of traditional rainfed rice accessions to brown spot, blast and sheath rot diseases. Indian Phytopath 48: 433-435

Singh L, Lal AA, Kumar K, Simon S, Kumar M. 2017. Management of brown spot disease of rice by safer fungicides and some bioagents. Plant Arch 17 (2): 1020-1022.

Singh RK, Singh CV, Shukla VD. 2013. Phosphorus nutrition reduces brown spot incidence in rainfed upland rice. Int Rice Res Notes 30 (2): 31-32.

Singh VP, Singh RC. 2000. Rain fed rice a sourcebook of best practices and strategies in Eastern India. IRRI Los Banos, Philippines.

Smith MOD, Simpson CE, Smith DH. 1994. Early and late leaf spot resistance and agronomic performance of nineteen interspecific derived peanut lines. Peanut Sci 21: 99-104

Srivastava R, Srivastava KK, Sarkar JD, Srivastava PR. 2010. Analysis of problems faced by the farmers in the adoption of control measures of diseases of rice. J Intl Acad 14 (2): 260-266

Vidhyasekaran P, Ramadoss N. 1973. Quantitative and qualitative losses in paddy due to Helminthosporiose epidemic. Indian Phytopath 26: 479-484.

VSN International. 2009. GenStat $12^{\text {th }}$ Edition for Windows. VSN International Ltd. www.vsni.co.uk.

Webster RK, Gunnell PS. 1992. Compendium of rice diseases. American Phytopathological Society, St. Paul, MN.

Zadoks JC. 2002. Fifty years of crop protection, 1950-2000. Neth J Agric Sci 2002: 181-193.

Zuckerman E, Eshel A, Eyal Z. 1997. Physiological aspects related to tolerance of spring wheat cultivars to Septoria tritici blotch. Phytopathol 87: 60-65. DOI: 10.1094/PHYTO.1997.87.1.60. 